\section{LIVING IN THE}

SAME HOUSE:

\section{AN INTERGENERATIONAL} COMPARATIVE

\section{Serhat ÖZTÜRK}

Assist.Prof.Dr., Hacettepe University

Faculty of Economics and Administrative

Sciences

Department of Family and Consumer

Sciences

sozturk@hacettepe.edu.tr

\section{Hülya ÖZTOP}

Assoc.Prof.Dr., Hacettepe University

Faculty of Economics and Administrative

Sciences

Department of Family and Consumer

Sciences

hoztop@ hacettepe.edu.tr
Hacettepe University Journal of Economics and Administrative Sciences

Vol. 36, Issue 1, 2018 pp. 105-117
A bstract: The aim of this study is to conduct the validity and reliability analysis of Turkish adaptation of 'Assessment Conflict in Coresidence with Elderly People' scale developed by Postigo and Honrubia (2010). The study involves 260 persons from three generations. Hacettepe University (Ankara) students are the sample of young generation. Their parents and grandparents are the sample of adult and older people generation. The results show that, there are significant differences between the responses of grandchildren and grandparents to the statements of 'Grandparents help with housework', 'Grandparents make emotionally unjust threats using their diseases', 'Grandparents are more tolerant than they were before'.

Keywords: Intergenerational relations, intergenerational conflict, coresidence with elderly people. 


\section{AYNI EVDE YAŞAMAK:}

\section{KUŞAKLARARASI BİR KARŞILAŞTIRMA}

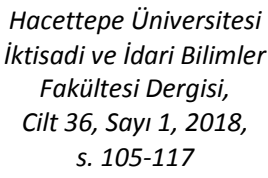

\section{Serhat ÖZTÜRK}

Dr.Öğr. Üyesi, Hacettepe Üniversitesi İktisadi ve İdari Bilimler Fakültesi Aile ve Tüketici Bilimleri Bölümü sozturk@hacettepe.edu.tr

\section{Hülya ÖZTOP}

Doç.Dr., Hacettepe Üniversitesi İktisadi ve İdari Bilimler Fakültesi Aile ve Tüketici Bilimleri Bölümü hoztop@ hacettepe.edu.tr z: Bu çalışmanın amacı, Postigo ve

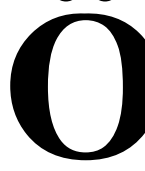
Honrubia (2010) tarafından geliştirilen 'Yaşlılarla Aynı Evde Yaşanan Çatışmanın Değerlendirilmesi' ölçeğinin Türkiye örneğinde geçerlik ve güvenirlik analizlerinin yapılmasıdır. Yapılan çalışma üç kuşağa ait 260 veri içermektedir. Hacettepe Üniversitesi'nde (Ankara) öğrenim gören öğrenciler genç nesil örneklemini oluşturmaktadır. Öğrencilerin ebeveynleri ve büyük ebeveynleri ise, yetişkin ve yaşlı bireylere ilişkin örneklemdir. Çalışmanın sonuçları, torunlar ve büyük ebeveynlerin, 'Büyük ebeveynler ev işlerine yardım ederler.', 'Büyük ebeveynler hastalıklarını bahane ederek duygusal tehditlerde bulunurlar.', 'Büyük ebeveynler eskiden olduklarına göre daha toleranslılardır.', ifadelerine verdikleri cevaplar arasında anlamlı farklılıklar bulunduğunu göstermektedir.

Anahtar Sözcükler: Kuşaklar arası ilişkiler, kuşaklar arası çatışma, yaşlılarla aynı evde yaşama. 
With the growth of populations in developed and developing countries, it becomes important to integrate older people populations into society, increase their efficiency and quality of life, and recognize the social value of elderliness (Guven, 2002: 243). Family is especially important in giving support, confidence, love and care to older people. Families can help older people to handle their problems, adapt to elderliness, feel like a respectable and well-esteemed person, and have a healthy and happy life (Oztop, Telsiz, 2001b: 58). Intergenerational solidarity is based on the relations of spouses, children and grandchildren. Accordingly, the preservation and persistence of family unity gain importance for society and older people (Sener $v d$., 2004: 43).

Technological, economic, social and cultural changes affect family life. As a result of the increase in economic status, health conditions, and social acceptance of elderliness in industrialized countries, older people began to live alone (Oztop, Telsiz, 2001a: 60). In Turkey, although the older people choose to live near their children's homes and have close relationships with them. Hence, solidarity in family life persists (Atalay, 1992: 126). It is hard to live with parents or grandparents in urban settings, but in villages extended family household life is still the norm. With women's participation in economic life, grandparents need to take care of the children when women are at work, and different generations live together. Moreover, taking care of the parents in their old age is perceived as a family responsibility, especially elder children give the most support to their elders and become a source of social communication (Chappell, 1991: 3; Oztop, Telsiz, 2001a: 60). Viewing helping and supportive relationships between grandchildren and grandparents as a shared responsibility creates positive family relationships (Sener $v d$. ., 2004: 45).

Grandchildren's coming into the world is an important event in family life, with an effect on three generations. Children become adults when they have a child, and they need advice and help from their own parents. Hence, they recognize the value of their parents and trust in them (Smith, 1999: 78). Conflicts in daily life and struggles for authority and status, arise less between grandparents and grandchildren compared to the relation between parents and children. Grandparents' communication with their grandchildren is generally benevolent, and grandparents, with their soothing role, reconcile conflicts arising between parents and children (Ciftci, 2008: 82). Older people devote their time and care to children. Hence, they make a valuable contribution, both morally and materially, to child care and education during important phases of children's life (Harper, Levin, 2005: 161). Grandparents positively affect children's lives by taking care of them, showing benevolence and love, playing games, giving advice and reconciling conflicts between children and parents (Ciftci, 2008: 78; Sener, 2009: 15). The mutual understanding of different generations and positive relationships between them are crucial for social harmony and peace (Canatan, 2008: 66). The 
importance of the relationship between grandparents and grandchildren for child development is gradually being recognized. The positive relationship between grandparents and grandchildren strengthens the cognitive capacity to learn new things, emotional development, prosperity of personality, feelings of pride and responsibility and taking pleasure and enjoyment (Smith, 1991: 91). Through their relationship with grandmothers and grandfathers, grandchildren learn to develop a positive attitude toward elderliness. They also recognize historical and cultural values and traditions, gain life experience, develop abilities, and learn to support their grandmother and grandfather and build friendships with them (Sener $v d$., 2004: 46). Older people ensure the persistence of cultural values and knowledge by transmitting experiences to the young (Canatan, 2008: 68; Baranowski, 1982: 577. Thus the interaction between different generations living in the same house is particularly important.

There is a growing interest in research on intergenerational perceptions and attitudes, communication, mutual aid and emotional support (Power, Eheart, 2001: 721; Keith, Wacker, 2002: 201; Drury, 2003: 65; McConatha vd., 2003: 210; Anderson vd., 2005: 287). Previous studies focused on beliefs about elderliness and the relation between divorce and children's age, gender, health condition, marital status, economics, love, and living space (Keith, Wacker, 2002: 196; Hill, 2006: 121). However, there are few studies on the experiences of different generations living in the same house and conflicts resulting from intergenerational differences. Some studies show that young people's attitudes towards older people and elderliness are moving in a positive direction (Postigo, Honrubia, 2010: 343; Hazer vd., 2015: 221); but there are also studies that indicate that young people have negative attitudes towards older people and growing old, and they are not eager to live with their elders (Belsky, 1998: 83; Postigo, Honrubia, 2010: 335).

When different generations live together, mutual support and collaboration improve in families. Older people make a variety of contributions to family life, e.g., material support, education, housework and child care (Postigo, Honrubia, 2010: 337). However, living in the same house can cause conflict between generations. Some of the conflicts arise from the physical conditions of the house, e.g., space in the home or a lack of belongings. Conflicts vary according to the personality and social status of older people. Older people in need of care and with diminishing cognitive capacity can often cause conflict with adult children. Family members who help elderly family members in need of care can suffer from stress (Gaugler $v d$., 2002: 205-231). If a positive relationship between an elderly person and adult children has been established previously, mutual support arises between adult children and an elderly person in need of care (Postigo, Honrubia, 2010: 336). When grandparents take responsibility for child care, there will probably be conflict with their adult children. This conflict can be avoided if grandparents are benevolent and have a positive attitude (Gerard $v d ., 2006$ : 
361). The reverse scenario may occur when grandchildren take responsibility for taking care of grandparents. Taking responsibility properly brings crucial benefits to a family (Fruhauf $v d ., 2006: 892$ ).

Strong family relationships are important to older people as a basis for mutual understanding of expectations and problem solving for children, parents and grandchildren. That is why this research was planned and conducted to determine and compare the beliefs and opinions of grandchildren, parents (adult children) and grandparents about living in the same house.

\section{METHOD}

\section{Sample}

This research involved 260 persons from three generations. Hacettepe University (Ankara) students were the sample of the young generation. Their parents and grandparents were the sample of adult and elderly generation. The research sample was limited to the students of Family and Consumer Sciences at Hacettepe University and their families, 260 persons in total. To generalize the research would need to be redone on a broader scale and in different areas.

\section{Data Collection Tools}

To determine the participants' beliefs and opinions about living in the same house with grandparents, a Turkish version of Postigo and Honrubia's (2010) 'Assessment Conflict in Coresidence With Elderly People' "Assessment Conflict in Coresidence With Elderly People" was used. The scale includes 20 items and is scored with a 5 point Likert scale (1- strongly disagree, and 5- strongly agree). The scale includes negative items $(3,5,7,8,12,13,16,17,19,20)$ and positive items $(1,2,4,6$, $9,10,11,14,15,18)$. The scale is composed of 5 factors. They named the factors as; Factor $1(3,5,7,8,12,13,17,19,20)$ Negative perception, Factor $2(1,6,14,15)$ Peaceful co-residence, Factor $3(2,4,18)$ Positive personality, Factor $4(9,11)$ Quality of life, Factor $5(10,16)$ Residential homes and space.

The "Assessment Conflict in Coresidence With Elderly People" was developed by Postigo and Honrubia (2010) and has high reliability level $(\alpha=0.90)$. An economic difficulties scale with 20 items summed up the total variance percentage of $47.5 \%$ and eigenvalue of 6.166 under five factors. Factor analysis and the alpha reliability test were used to evaluate the validity and reliability of the scale for Turkish society.

After consultation with experts and a trial survey, a 20 item scale was used to survey the group of 260 participants chosen by simple random sampling. An internal consistency test was applied to the findings, and the general reliability of test was 
calculated. It was found that tenth item, 'Nursing homes are the best solution for grandparents' reduced the internal consistency, and it was deleted from the scale. Finally, factor analysis was applied to the data. The Cronbach alpha coefficient was calculated for the internal consistency of each factor.

Items on the 'Evaluation scale for conflicts which arise from living in the same house with grandparents' were summed up under five factors. The total variance ratio of the scale was $54.57 \%$, and the eigenvalue was above 1.000 for each factor. Hence, the total variance ratio of scale was adequate. The factor load of the items on the scale was between the values 0.48 and 0.75 . These values were considered an adequate validity structure for the scale. The internal consistency coefficient (Cronbach Alpha coefficient) of the scale was 0.80 . These findings indicate that the scale had high validity and reliability for Turkish society.

\section{The Evaluation Scale for Conflicts Which Arise from Living in the Same House with Elders}

Validity structure studies were done to determine the scale's validity. Factor analysis was done for validity structure and factor loads of scale items were found.

Factor Analysis: Principle component analysis was used for scale factor analysis. Before application, scale was composed of 20 items. Factor analysis found the factor load of the tenth item, 'Nursing homes are the best solution for grandparents' to be below 0.01 , and this item was deleted from the scale. The remaining 19 items were summed up under 5 factors. Table 1 . shows factor loads of the items remained in the scale.

After the tenth item was deleted, the items on the scale were distributed under five factors, and their factor loads were between 0.48 and 0.75 . Five factors explain $54.57 \%$ of the total variance. When items were involved with other factors they were ranked, and loads were apparently low. The difference between loads was above 0.10 . The Eigen value of the first factor was 4.20, and the other 4 factors were above 1.00 . This result showed that the 19 item scale had a valid structure.

The Scale's Internal Consistency: After the tenth item was deleted, the scale's internal consistency (Cronbach alpha coefficient) was calculated. The alpha coefficient indicating the items' internal consistency was 0.80 . This value indicates that the entire scale has internal consistency. If one of the items is deleted, the value cannot increase significantly over 0.80 . Hence, we can say that ranking all items in the scale will increase its reliability. 
Table 1. Principal Components Analysis- 'Assessment of Conflict in Co-Residence with Elderly

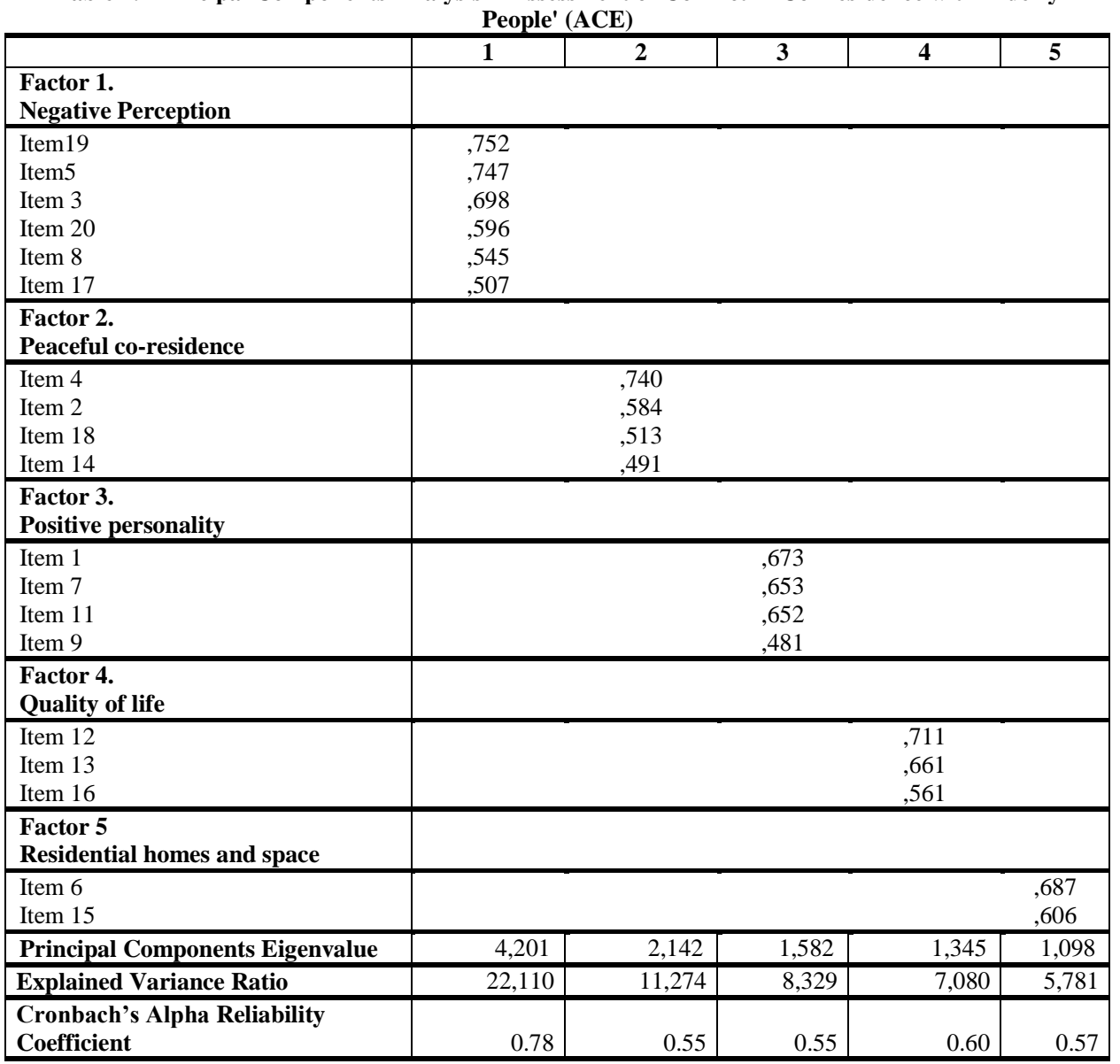

The internal consistency coefficient of the sub-scale composed of the first factor items $(3,5,8,17,19,20)$ was 0.78 . There will be no increase in value if an item is eliminated. Thus the internal consistency of the second factor items is high. Second factor is composed of 4 items $(2,4,14,18)$. The internal consistency coefficient of the sub-scale of the items was 0.55 , and there will be no increase in value if an item is eliminated. Thus the internal consistency of the second factor items is high. Third factor is composed of 4 items $(1,7,9,11)$. The internal consistency coefficient of sub-scale of the items was 0.55 . The fourth factor is composed of 3 items $(12,13,16)$, and its internal consistency coefficient is 0.60 . The fifth factor is composed of 2 items $(6,15)$ and had an internal consistency coefficient value of 0.57 . There will be no increase in value if an item is eliminated. Thus the internal consistency of these factor items is high (Table 1.) 


\section{DATA ANALYSIS}

The "Assessment Conflict in Coresidence With Elderly People" was used to survey Family and Consumer Sciences students living with their parents and grandparents, who were contacted and agreed to respond to the survey. Moreover, they collaborated with us by having their parents and grandparents' participate in the survey. We gave numbers to the surveys that each student gave to their parents and grandparents, and classified the families. In cases of incomprehensible questions in the survey, the students were requested to ask for help from the researchers within 15 days.

Researchers evaluated data obtained from the research with SPSS 22.0 software. A One Way Anova Test found significant differences between age groups. To determine which groups manifest these differences, the groups were compared with each other. Tukey's HSD test was used for the comparison.

\section{FINDINGS}

Of the research participants, $79.2 \%$ were female, $34.2 \%$ were children (grandchildren) under 30 years of age, $41.9 \%$ were parents or adult children between 30 and 60 years of age, $23.8 \%$ were aged 60 years and above (grandparents or elders), $41.5 \%$ were single, $30.8 \%$ work full-time, $47.7 \%$ live with 3 persons or less, $63.8 \%$ said they were in good health, $81.5 \%$ said they had a medium monthly income, $70.8 \%$ were homeowner family members and $42.7 \%$ had 3 bedrooms in their home.

Analysis of the Relation between Age Groups (Grandchildren, Parents and Grandparents) and the Evaluation Scale for Conflicts which Arise from Living in the Same House with Grandparents

A One Way Anova Analysis shows that age groups (grandchildren, parents and grandparents) affect the point averages of responses to statements in the "Assessment Conflict in Coresidence With Elderly People" (ACE). To determine which statements and groups create these differences, the age groups were compared; how certain scale statements relate to certain groups according to Tukey's HSD test.

There is a significant difference between the averages of grandchildren and grandparents in response to the statements, 'Grandparents help with housework,' 'Grandparents make emotionally unjust threats using their diseases,' 'Grandparents are more tolerant than they were before' $(\mathrm{P}<0.05)$.

There is a significant difference between the averages of grandchildren and grandparents in the average of responses to the statement, 'Grandparents entertain their grandchildren by telling stories about their past' $(\mathrm{P}<0.05)$. There is a significant difference between the averages of grandchildren and grandparents' response to the 
statement, 'Grandparents are more tranquil than they were before' $(\mathrm{P}<0.05)$. There is a significant difference between the averages of grandchildren and parents, and between the averages of grandchildren and grandparents in response to the statement, 'Conflicts within the family can be avoided if grandparents remain silent' $(\mathrm{P}<0.01)$. There is a significant difference between the averages of grandchildren and grandparents in response to the statement, 'In homes where grandparents live, there is no privacy for couples' $(\mathrm{P}<0.01)$. There is a significant difference between the averages of grandchildren and grandparents in response to the statement, 'In the homes where grandparents live, conflicts arise less' $(\mathrm{P}<0.01)$. There is a significant difference between the averages of grandchildren and grandparents, and between the averages of parents and grandparents in response to the statement 'Grandparents ask you day by day to spend more time with them' $(\mathrm{P}<0.05)$. There is a significant difference between grandchildren and grandparents, and between the averages of parents and grandparents in response to the statement, 'You cannot argue with grandparents since they think they know everything' $(\mathrm{P}<0.01)$.

No significant difference was found between the averages of grandchildren and parents, parents and grandparents, and grandchildren and grandparents in response to the statements 'Grandparents want you to devote all of your time to them,' 'It is comfortable to share a home with grandparents,' 'Grandparents neglect personal hygiene,' 'Grandparents' remissness and forgetfulness are dangerous in the home,' 'Grandparents can be autonomous and free,' 'Grandparents can have a high quality of life,' 'In homes where grandparents live, couples can go out easily,' 'Grandparents occupy many empty space in home,' and 'Grandparents don't trust anybody, and they think that everybody deceives them' $(\mathrm{P}>0.05)$.

\section{DISCUSSION AND CONCLUSION}

This study seeks to compare the views of three generations, grandparents, parents and grandchildren, about living in the same house. The "Evaluation scale for conflicts which arise from living in the same house with grandparents," developed by Postigo and Honrubia (2010), was adapted for use in Turkey. The tenth item, "Nursing homes are the best solution for grandparents" was found to reduce internal consistency and deleted from the scale. According to the results of analyzing the remaining items, the scale was found to be valid and reliable for Turkey.

The research participants from three generations had positive and negative beliefs and opinions. In a study done in Spain, by Postigo \& Honrubia (2010), the positive attitude towards the item 'Grandparents help with housework' was found to be similar to attitudes in Turkey. Postigo and Honrubia's (2010) study revealed a negative attitude towards grandparents with regard to the item, 'Grandparents occupy too much space in home,' like our study in Turkey. In both studies, grandchildren, parents and 
grandparents agreed with the item, 'Conflicts within the family can be avoided if grandparents remain silent. 'Statistical analysis found that the differences between grandchildren and parents, and between grandchildren and grandparents, were significant. Grandchildren had the highest average levels of agreement, and grandparents, the lowest.

The highest levels of agreement with the item, 'Grandparents make emotionally unjust threats using their diseases,' was found in grandparents. We can consider grandparents' high level of agreement as an instance of self-critique. Yet it reveals that grandparents are in need of care. By age group, grandparents had the highest level of average agreement, and children, the lowest. The difference between grandchildren and grandparents was found to be statistically significant. In Postigo and Honrubia's (2010) study, adult children had the highest percentage of agreement. The differences between grandchildren and parents, and between parents and grandparents, were found to be statistically significant, but the difference between grandchildren and grandparents was found not to be statistically significantly.

While in our study no statistically significant difference was found between generations who agreed with the item 'In homes where grandparents live, couples can go out easily,' in Postigo and Honrubia's (2010) study, only the grandparents agreed with this item. The differences between grandchildren and parents, and between parents and grandparents, were found to be statistically significant.

By age group, grandparents had the highest levels of average agreement concerning the item 'You cannot argue with grandparents since they think they know everything,' and grandchildren the lowest. The differences between grandchildren and grandparents, and between parents and grandparents, were statistically significant. In Postigo and Honrubia's (2010) study similar results were obtained.

There are certain limitations to this study. Since the study sample is limited to Hacettepe University Family and Consumer Sciences students and their families (260 persons), this research needs to be redone using a larger sample in regions with varying socioeconomic levels. Additionally, doing this kind of research in different cultures and making intercultural comparisons can bring crucial results to help develop solutions for the problems confronting families, the most important source of informal support for grandparents' care. 


\section{KEY POINTS}

$\checkmark \quad$ The item, "Nursing homes are the best solution for grandparents" was found to reduce internal consistency and deleted from the scale which is used in Spain. According to the results of analyzing the remaining items, the scale was found to be valid and reliable for Turkey.

There is a significant difference between the averages of grandchildren and grandparents in response to the statements, 'Grandparents help with housework,' 'Grandparents make emotionally unjust threats using their diseases,' 'Grandparents are more tolerant than they were before' $(\mathrm{P}<0.05)$.

By age group, grandparents had the highest levels of average agreement concerning the item 'You cannot argue with grandparents since they think they know everything,' and grandchildren the lowest.

\section{REFERENCES}

Anderson, K., J. Harwood, M.L. Hummert (2005), “The Grandparent-Grandchild Relationship: Implications for Models of Intergenerational Communication", Human Communication Research, 31, 268-294.

Atalay, B. (1992), Turkish Family Structure Research, Ankara: Prime Ministry State Planning Organization.

Baranowski, M.D. (1982), “Grandparent-Adolescent Relations: Beyond the Nuclear Family”, Adolescence, 17(67), 575.

Belsky, J. (1998), “The Psychology of Aging: Theory”, Research and Interventions. Clearwater, FL: Seashellbooks.com.

Canatan, A. (2008), "Social Values and Elders”, Elders Issues Research Journal, 1, 62-71.

Chappell, N.L. (1991), "Living Arrangements and Sources of Caregiving", Journal of Gerontolog, 46(1), 1-8.

Ciftci, A. (2008), Elder Persons in Family, Family Council V, Family Support Services Bulletin, Ankara: Turkish Republic Prime Ministry Family and Social Research General Directorate.

Drury, J. (2003), "Adolescent Communication with Adults in Authority", Journal of Language and Social Psychology, 22, 66-72.

Fruhauf, C.A., S.E. Jarrott, K.R. Allen (2006), “Grandchildren's Perceptions of Caring for Grandparents", Journal of Family Issues, 7, 887-911.

Gaugler, J.E., R.L. Kane, R.A. Kane (2002), "Family Care for Older Adults with Disabilities: Toward more Targeted and Interpretable Research", International Journal of Aging and Human Development, 4, 205-231.

Gerard, J.M., L. Landry-Meyer, J.G. Roe (2006), “Grandparents Raising Grandchildren: The Role of Social Support in Coping with Caregiving Challenges", International Journal of Aging \& Human Development, 62, 359-383. 
ÖZTÜRK | Aynı Evde Yaşamaya İlişkin Görüşler: Kuşaklararası Bir Karşıllaştırma

Guven, S. (2002), Elder and Family, Geriatrics (Ed. Gokce, Y.), Hacettepe University, Journal of Geriatrics Sciences Research and Application Center, Istanbul: Turgut, 241-247.

Hacettepe University, Institute of Population Etudes (2008), Turkey Population Health Research, http://www.hips.hacettepe.edu.tr/tnsa2008/data/TNSA-2008_ana_Rapor-tr.pdf, [access date November, 2012].

Harper, S., S. Levin (2005), "Family Care, Independent Living and Ethnicity", Social Policy and Society, 4, 157-169.

Hazer, O., M.S. Ozturk, N. Gursoy (2015), "Effects of Intergenerational Solidarity on the Satisfaction with Life", International Journal of Arts \& Sciences, 08(01), 213-229.

Hill, T.J. (2006), "Grandchild, Grandparent, and Parent Coresidence from 1970 to 1990: Structural Factors Affecting State Patterns", International Journal of Aging \& Human Development, 62, 117-142.

Keith, P., R. Wacker (2002), "Grandparent Visitation Rights: An Inappropriate Intrusion or Appropriate Protection?", International Journal of Aging and Human Development, 4, 191-204.

McConatha, J.T., F. Schnell, K. Volkwein, E. Leach (2003), "Attitudes Toward Aging: A Comparative Analysis of Young Adults from the United States and Germany", International Journal of Aging and Human Development, 7, 203-215.

Ministry of Family \& Social Policies Family Structure Research, (2011), http://www.ailetoplum.gov.tr/upload/athgm.gov.tr/mce/2013/taya kitap butun.pdf, [access date December 20, 2013.].

Oztop, H, M. Telsiz (2001a), "Elder Parents' Relationship with their Adult Children and their Expectations: A Comparative Study of Generations", H.U. Domestic Economy Y.O. 7(7), 57-62.

Oztop, H., M. Telsiz (2001b), “Elder Parents' Relationship with their Adult Children”, Elders' Issues Research Journal, 1(1), 57-62.

Postigo, J.M.L., R.L. Honrubia (2010), "The Co-Residence of Elderly People with their Children and Grandchildren", Educational Gerontology, 6, 330-349.

Power, M.B., B.K. Eheart (2001), "Crisis in Foster Home: The Need for a Caring Community", Children and Youth Services Review, 3(9-19), 719-742.

Sener, A. (2009), "Elderliness, Life Satisfaction and Free Time Activities", Hacettepe University Sociological Research e-journal, 1-18.

Sener, A., H. Oztop, S. Guven (2004), "Elder People and Family. Healthy and Successful Elderliness", 39-49, Ankara: H.U. Geriatrics Sciences Research Center.

Smith, P.K. (Ed.), (1991), The Psychology of Grandparenthood: An International Perspective, London: Routledge.

Smith, S. (1999), Family Relationships in Later Life. University of Florida Extension Service. http://edis.ifas.ufl.edu/BODX_HE020; [access date November, 2012].

World Health Organization (2002), Lessons for Long-Term Care Policy WHO/NMH/CCL/02.1.2002. 